\title{
Konvergensi Hukum Penentuan Suku Bunga dalam Layanan Pinjam Meminjam Uang Berbasis Teknologi Informasi
}

\section{Sofwan Rizko Ramadoni ${ }^{1}$, Sukarmi ${ }^{2}$, Hanif Nur Widhiyanti ${ }^{3}$}

1Fakultas Hukum Universitas Brawijaya, E-mail: rizkoramadoni@gmail.com

${ }^{2}$ Fakultas Hukum Universitas Brawijaya, E-mail: sukarmi08@yahoo.com

3Fakultas Hukum Universitas Brawijaya, E-mail: hanifnurwidhiyanti@gmail.com

\begin{tabular}{l}
\hline Info Artikel \\
Masuk: 13 September 2020 \\
Diterima: 28 Desember 2020 \\
Terbit: 31 Desember 2020 \\
Keywords: \\
Financial Technology; Interest \\
rate; Legal Convergence; Peer \\
to Peer Lending \\
Corresponding Author: \\
rizkoramadoni@gmail.com \\
DoI: \\
xxxxxxx \\
Hukum; Teknologi Finansial; \\
Peer to Peer Lending \\
Kunci:
\end{tabular}

\begin{abstract}
The existing legal construction of information technology-based loaning services essentially creates high interest rates in the community and leads to non-performing loans. Therefore, in essence, it is necessary to formulate a new legal construction to solve these problems. Considering that the problem is complex and systemic, ideally the legal construction formulated is convergence, which is the result of the unification of all existing variables. Related to this, the question arises how the legal construction of determining interest rates in information technology-based loaning services reflects the convergence of law and the principle of justice. The purpose of this study is to identify, describe and analyze the application of the legal construction of determining interest rates in information technology-based loaning services in the future. The research method used in this study is a normative juridical research using a statutory approach, a conceptual approach and a convergence approach. The results of this legal research indicate that the legal construction of determining interest rates in information technology-based loaning services which reflects the convergence of law and the principle of justice is the determination of interest rates that refer to the interest rates set by Bank Indonesia.
\end{abstract}

\begin{tabular}{l}
\hline Abstrak \\
\hline Konstruksi hukum layanan pinjam meminjam uang berbasis \\
teknologi informasi eksisting saat ini pada hakikatnya \\
menciptakan penetapan suku bunga yang tinggi di masyarakat \\
dan marak berujung kepada non performing loan. Maka dari itu \\
pada hakikatnya perlu dirumuskan sebuah konstruksi hukum \\
baru untuk dapat memecahkan permasalahan tersebut. \\
Mengingat permasalahan tersebut bersifat kompleks dan \\
sistemik, maka idealnya konstruksi hukum yang dirumuskan \\
bersifat konvergensi, yakni merupakan hasil dari penyatuan \\
seluruh variabel-variabel yang ada. Terkait hal tersebut muncul \\
lah pertanyaan bagaimana konstruksi hukum penentuan suku \\
bunga dalam layanan pinjam meminjam uang berbasis teknologi \\
informasi yang mencerminkan prinsip konvergensi hukum dan \\
prinsip keadilan. Tujuan Penelitian ini adalah untuk \\
mengidentifikasi, mendeskripsikan dan menganalisis mengenai \\
penerapan konstruksi hukum dari penentuan suku bunga dalam \\
layanan pinjam meminjam uang berbasis teknologi informasi di
\end{tabular}


masa yang akan mendatang. Metode penelitian yang digunakan pada penelitian ini merupakan jenis penelitian yuridis normatif dengan menggunakan pendekatan perundang-undangan, pendekatan konseptual dan pendekatan konvergensi. Hasil penelitian hukum ini menunjukkan bahwa Konstruksi hukum penentuan suku bunga dalam layanan pinjam meminjam uang berbasis teknologi informasi yang mencerminkan prinsip konvergensi hukum dan prinsip keadilan adalah penentuan suku bunga yang mengacu kepada suku bunga yang ditetapkan oleh Bank Indonesia.

\section{Pendahuluan}

Penerapan platform teknologi informasi dalam kegiatan bisnis di Indonesia adalah sebuah trend model bisnis yang tidak dapat terhindarkan. Khususnya pada kegiatan layanan pinjam meminjam uang berbasis teknologi informasi, apabila melihat perkembangan trend dalam 2 tahun terakhir, kegiatan bisnis tersebut terlihat sangat prospektif. Berdasarkan laporan Otoritas Jasa Keuangan (selanjutnya disebut OJK), per bulan Juli 2019 terdapat 127 penyelenggara kegiatan layanan pinjam meminjam uang berbasis teknologi informasi yang telah terdaftar serta memperoleh izin berusaha dari OJK yang 8 diantaranya merupakan berbentuk syariah dan sisanya 119 berbentuk konvensional. ${ }^{1}$ Adapun jumlah tersebut berpotensi lebih meningkat dibanding sebelumnya, sebab hingga saat ini terdapat 16 perusahaan sedang dalam proses pendaftaran, 112 perusahaan yang permohonan pendaftarannya dikembalikan oleh OJK dan 22 perusahaan yang berminat untuk mendaftar perizinan. ${ }^{2}$ Lebih lanjut, total jumlah pinjaman yang tersalurkan hingga bulan Juli 2019 sebesar Rp. 49,79 Triliun, meningkat sebesar 119,69\% dibandingkan di periode tahun 2018 sebesar Rp. 22,66 Triliun. ${ }^{3}$ Hal tersebutlah yang menjadi faktor utama yang menyebabkan bisnis kegiatan layanan pinjam meminjam uang berbasis teknologi informasi terlihat sangat prospektif, yang kemudian berdampak juga kepada berkembang pesatnya kegiatan layanan pinjam meminjam uang berbasis teknologi informasi.

Namun dibalik fenomena tersebut, kegiatan layanan pinjam meminjam uang berbasis teknologi informasi juga memiliki berbagai permasalahan di masyarakat. Berdasarkan observasi Peneliti, di tahun 2019 tercatat sebanyak 16 laporan pengaduan permasalahan dari debitur atau pengguna terhadap kegiatan layanan pinjam meminjam uang berbasis teknologi informasi kepada OJK melalui platform daring LAPOR!, diantaranya terkait penyebaran data pribadi nasabah yang dilakukan oleh debt collector dan besarnya tunggakan bunga pinjaman. ${ }^{4}$ Terkait kedua hal tersebut, pada hakikatnya bersumber pada satu masalah yang sama, yakni disebabkan oleh

1 Otoritas Jasa Keuangan. Perkembangan Fintech Lending (Pendanaan Gotong Royong on-Line). https://www.ojk.go.id/id/kanal/iknb/data-danstatistik/fintech/Pages/Statistik-Fintech-Lending-Periode-Juli-2019.aspx (Diakses pada tanggal 18 September 2019).

${ }^{2}$ Ibid.

${ }^{3}$ Ibid.

4 LAPOR. Otoritas Jasa Keuangan. https://www.lapor.go.id/instansi/otoritas-jasakeuangan/process (Diakses pada tanggal 4 Juli 2019). 
gagal bayar atau pinjaman bermasalah (non performing loan) dalam kegiatan layanan pinjam meminjam uang berbasis teknologi informasi. ${ }^{5}$

Adapun faktor utama penyebab gagal bayar atau pinjaman bermasalah (non performing loan) tersebut adalah tingginya bunga beserta denda yang ditetapkan penyelenggara kegiatan layanan pinjam meminjam uang berbasis teknologi informasi kepada debitur atau penerima pinjaman, yang umumnya adalah masyarakat dengan kemampuan finansial menengah ke bawah. Adapun bunga yang ditawarkan oleh kegiatan layanan pinjam meminjam uang berbasis teknologi informasi umumnya menggunakan mekanisme bunga flat sebesar 0,8\% bahkan hingga 10\% per hari dengan tenor dan angsuran yang sifatnya bervariasi. Beragamnya besaran suku bunga yang ditawarkan tersebut karena secara yuridis hal tersebut sepenuhnya menjadi kewenangan dari penyelenggara kegiatan layanan pinjam meminjam uang berbasis teknologi informasi, sebagaimana amanat dari Pasal 17 Ayat (1) Peraturan Otoritas Jasa Keuangan Nomor 77/POJK.01/2016 tentang Layanan Pinjam Meminjam Uang Berbasis Teknologi Informasi ${ }^{6}$ (Selanjutnya disebut POJK Nomor 77 Tahun 2016), yakni ditentukan oleh penyelenggara berdasarkan kepada pertimbangan kewajaran dan perkembangan perekonomian nasional.

Berdasarkan ketentuan tersebut maka semestinya besaran suku bunga yang ditetapkan oleh penyelenggara kegiatan layanan pinjam meminjam uang berbasis teknologi informasi dapat diterima secara rasional dan minim resiko gagal bayar (non performing loan). Namun faktanya, dalam penyelenggaraan kegiatan layanan pinjam meminjam uang berbasis teknologi informasi eksisting masih banyak terdapat penentuan besaran suku bunga yang tidak wajar dan tidak jarang berimplikasi kepada gagal bayar atau pinjaman bermasalah (non performing loan). ${ }^{7}$ Karena pada hakikatnya calon debitur layanan pinjam meminjam uang berbasis teknologi informasi pun tidak memiliki pilihan lain selain menerima besaran suku bunga tersebut secara sepihak dari penyelenggara layanan pinjam meminjam uang berbasis teknologi informasi apabila sepakat untuk menggunakan layanan pinjam meminjam uang berbasis teknologi informasi tersebut. ${ }^{8}$ Dengan demikian dalam hal ini Pasal 17 Ayat (1) POJK Nomor 77 Tahun 2016 selain menimbulkan ketidakpastian dalam praktik penentuan suku bunga di dalam penyelenggaraan layanan pinjam meminjam uang berbasis teknologi informasi juga menciptakan posisi yang tidak seimbang dalam perjanjian antara debitur dengan kreditur.

Padahal kondisi tersebut secara langsung berpengaruh terhadap stabilitas sistem keuangan. Hal tersebut dikarenakan pinjaman bermasalah (non performing loan) merupakan salah satu faktor utama dari permasalahan makroekonomi. Berefleksi dari kejadian krisis moneter di tahun 1998, tercatat bahwa terdapat pinjaman bermasalah

${ }^{5}$ Otoritas Jasa Keuangan. Perkembangan Fintech Lending (Pendanaan Gotong Royong on-Line). Loc. Cit.

${ }^{6}$ Pasal 17 Ayat (1) Peraturan Otoritas Jasa Keuangan Nomor 77/POJK.01/2016 tentang Layanan Pinjam Meminjam Uang Berbasis Teknologi Informasi: "Penyelenggara memberikan masukan atas suku bunga yang ditawarkan oleh Pemberi Pinjaman dan Penerima Pinjaman dengan mempertimbangkan kewajaran dan perkembangan perekonomian nasional."

7 Budiyanti, E. (2019). Upaya Mengatasi Layanan Pinjaman Online Ilegal. Info Singkat, 11(4), 19-24. h. 21.

8 Saputra, A. S. (2019). Peer To Peer Lending di Indonesia dan Beberapa Permasalahannya. Veritas et Justitia, 5(1), 238-261. h. 241. 
(non performing loan) hampir 50\%. Adapun salah satu penyebab utama yang menyebabkan hal tersebut terjadi adalah lemahnya regulasi pada saat itu yang secara tidak langsung membangun sistem keuangan nasional yang berpotensi dan rentan terhadap resiko sistemik. ${ }^{9}$ Hal tersebut tidak lain dikarenakan pada waktu itu Bank Indonesia (selanjutnya disebut BI) masih merupakan corong dari arah kebijakan Pemerintah. Sehingga pada tahun 1999, menandai awal mulanya pergantian rezim dari orde baru ke reformasi, BI menjadi lembaga negara yang independen dalam menetapkan kebijakan moneter. Adapun langkah awal kebijakan moneter yang dijalankan oleh BI dalam menjaga stabilitas sistem keuangan salah satunya adalah pemantauan terhadap sektor kredit dan sektor suku bunga perbankan. Hal tersebut dilakukan oleh BI semata-mata untuk menjaga kestabilan sistem moneter dalam makroekonomi di Indonesia. Sebab, terkait suku bunga hal tersebut secara tidak langsung mempengaruhi sektor kegiatan perekonomian, ketika kondisi suku bunga tinggi maka akan mempengaruhi perilaku masyarakat untuk berinvestasi, namun dampaknya memberatkan kepada masyarakat penerima modal investasi. Sehingga atas dasar rasionalitas tersebut BI pada akhirnya hadir sebagai penentu kebijakan dalam penentuan suku bunga dalam kegiatan intermediasi di Indonesia.

Berbeda halnya dengan kegiatan layanan pinjam meminjam uang berbasis teknologi informasi, seperti yang telah diketahui, hingga saat ini dalam hal penentuan suku bunga tidak ada otoritas yang menengahi dan menjadi penentu suku bunga dalam kegiatan layanan pinjam meminjam uang berbasis teknologi informasi. Kehadiran OJK sendiri hanya sebatas mengawasi kegiatan jasa keuangan yang ada di dalamnya, sebagaimana mengacu kepada amanat dari Pasal 6 Undang-Undang Nomor 21 Tahun 2011 tentang Otoritas Jasa Keuangan ${ }^{10}$ (Selanjutnya disebut UU Nomor 21 Tahun 2011).

Berdasarkan hal-hal tersebut di atas dapat diketahui bahwa terdapat sebuah ketidakpastian hukum terkait penentuan suku bunga dalam penyelenggaraan layanan pinjaman online di Indonesia, yang hal tersebut secara tidak langsung menjadi sumber utama dari permasalahan gagal bayar atau pinjaman bermasalah (non performing loan). Dengan demikian atas dasar hal tersebut pada hakikatnya perlu dirumuskan sebuah konstruksi hukum yang baru untuk dapat memecahkan permasalahan-permasalahan tersebut, mengingat permasalahan tersebut bersifat kompleks dan sistemik, maka sangatlah penting untuk melihat permasalahan tersebut secara keseluruhan, tidak hanya terbatas menggunakan pendekatan hukum saja, namun juga menggunakan pendekatan lainnya yang relevan seperti ekonomi, teknologi hingga keadilan. Terkait hal tersebut, dalam hal ini yang paling relevan digunakan adalah sebuah pendekatan konvergensi hukum, yakni dimana sebuah permasalahan hukum ditelaah tidak hanya variabel hukumnya saja, akan tetapi juga melibatkan keseluruhan variabel yang melekat pada permasalahan konkrit yang ada, dalam hal ini meliputi variabel hukum, variabel ekonomi, variabel teknologi dan variabel keadilan. Terkait hal tersebut

\footnotetext{
${ }^{9}$ Mustaqim, A. H. (2010). Otoritas Jasa Keuangan Sebagai Solusi Sistem Ekonomi Nasional. Jurnal Hukum Perspektif, 8 (1), 70-80. h. 77.

10 Pasal 6 Undang-Undang Nomor 21 Tahun 2011 tentang Otoritas Jasa Keuangan: “OJK melaksanakan tugas pengaturan dan pengawasan terhadap:

a. Kegiatan jasa keuangan di sektor Perbankan;

b. Kegiatan jasa keuangan di sektor Pasar Modal; dan

c. Kegiatan jasa keuangan di sektor Perasuransian, Dana Pensiun, Lembaga Pembiayaan, dan Lembaga Jasa Keuangan Lainnya."
} 
muncul lah pertanyaan bagaimana konstruksi hukum penentuan suku bunga dalam layanan pinjam meminjam uang berbasis teknologi informasi yang mencerminkan prinsip konvergensi hukum dan prinsip keadilan. Tujuan Penelitian ini adalah untuk mengidentifikasi, mendeskripsikan dan menganalisis mengenai penerapan konstruksi hukum dari penentuan suku bunga dalam layanan pinjam meminjam uang berbasis teknologi informasi di masa yang akan mendatang.

Adapun terdapat beberapa penelitian sejenis seperti yang dilakukan oleh Komang Satria Wibaya Putra dan I Nyoman Budiana pada tahun 2019 mengenai Perjanjian Kredit Melalui Financial Technology dalam Lalu Lintas Hukum Bisnis dengan fokus membahas perjanjian kredit di dalam perjanjian pinjam meminjam uang berbasis teknologi informasi secara keabsahan perjanjiannya, penetapan bunga yang seharusnya dan bentuk pertanggung jawabannya menurut Kitab Undang-Undang Hukum Perdata dan POJK Nomor 77 Tahun 2016. ${ }^{11}$ Otih Handayani dan Adi Sulistiyono pada tahun 2020 mengenai Pembadanan Hukum Fintech Sebagai Instrumen Pengaturan Persaingan Usaha yang Sehat dengan fokus membahas bagaimana pembadanan hukum layanan pinjam meminjam uang berbasis teknologi informasi dan Undang-Undang Nomor 5 Tahun 1999 tentang Larangan Praktek Monopoli dan Persaingan Usaha Tidak Sehat dapat memayungi kepentingan pelaku usaha, pesaing, dan pengguna jasa di dalamnya. ${ }^{12}$ Antoni Tjandra pada tahun 2020 mengenai Kekosongan Norma Penentuan Bunga Pinjaman Financial Technology Peer to Peer Lending dengan fokus membahas kekosongan norma hukum di dalam penentuan suku bunga pada kegiatan layanan pinjam meminjam uang berbasis teknologi informasi. ${ }^{13}$

Perbedaan antara penelitian sebelumnya adalah penelitian ini berusaha melakukan sebuah konstruksi hukum melalui pendekatan konvergensi hukum terhadap kekosongan hukum pada penentuan suku bunga dalam layanan pinjam meminjam uang berbasis teknologi informasi, sebagaimana merupakan sebuah inti permasalahan hukum yang ada pada penelitian sebelumnya. Dengan melakukan pendekatan konvergensi hukum, harapannya gagasan konstruksi hukum yang ditawarkan oleh penelitian ini bersifat lebih konstruktif dan komprehensif menjawab permasalahan tersebut.

\section{Metode Penelitian}

Penelitian ini merupakan jenis penelitian yuridis normatif (normative legal research), yakni suatu proses atau tahapan ilmiah yang bertujuan untuk menemukan aturan, prinsip, maupun doktrin hukum guna menjawab isu hukum yang ada di dalam penelitian ini. Sehingga metode penelitian hukum normatif berparadigma kepada inventarisir hukum positif, termasuk asas-asas serta doktrin hukum, melakukan penemuan hukum dalam perkara yang konkrit, sistematika hukum, telaah

${ }^{11}$ Putra, K. S. W. \& Budiana, I. N. (2019). Perjanjian Kredit Melalui Financial Technology Dalam Lalu Lintas Hukum Bisnis. Jurnal Analisis Hukum, 2(1), 73-92.

${ }^{12}$ Handayani, O. \& Sulistiyono, A. (2020). Pembadanan Hukum Fintech Sebagai Instrumen Pengaturan Persaingan Usaha yang Sehat. Masalah-Masalah Hukum, 49(3), 244-255.

${ }^{13}$ Tjandra, A. (2020). Kekosongan Norma Penentuan Bunga Pinjaman Financial Technology Peer To Peer Lending. Jurnal Hukum Bisnis Bonum Commune, 3(1), 90-103. 
sinkronisasi, perbandingan serta historis atau sejarah hukum. ${ }^{14}$ Adapun Peneliti dalam hal ini memilih menggunakan metode penelitian berupa pendekatan perundangundangan (statute approach), pendekatan konseptual (conceptual approach) dan pendekatan konvergensi (convergence approach). Pendekatan perundang-undangan dilakukan dengan menelaah semua undang-undang dan regulasi yang terkait dengan isu hukum dan kandungan filosofis suatu perundang-undangan serta untuk mempelajari adakah konsistensi dan kesesuaian ketentuan-ketentuan yang ada dalam suatu undang-undang antara suatu undang-undang dengan undang-undang lainnya. ${ }^{15}$ Terkait pendekatan konseptual berparadigma kepada pandangan atau doktrin yang berkembang di dalam studi ilmu hukum yang relevan terhadap fokus permasalahan. Pemahaman terhadap perundang-undangan yang ada serta kumpulan doktrin tersebut menjadi landasan bagi peneliti untuk membangun sebuah argumentasi untuk memberikan pandangan terkait konvergensi hukum penentuan suku bunga dalam layanan pinjam meminjam uang berbasis teknologi informasi. Sedangkan pendekatan konvergensi digunakan dengan melihat keterkaitan antara seluruh variabel-variabel yang relevan di dalam layanan pinjam meminjam uang berbasis teknologi informasi, di antaranya: variabel teknologi finansial, variabel makroekonomi dan variabel harmonisasi hukum. ${ }^{16}$

\section{Hasil dan Pembahasan}

\subsection{Konstruksi Hukum Penentuan Suku Bunga Dalam Layanan Pinjam Meminjam Uang Berbasis Teknologi Informasi yang Mencerminkan Prinsip Konvergensi Hukum dan Prinsip Keadilan}

Konstruksi hukum penentuan suku bunga dalam layanan pinjam meminjam uang berbasis teknologi informasi eksisting saat ini pada hakikatnya berparadigma kepada POJK Nomor 77 Tahun 2016, dimana pada asas penyelenggaraannya penentuan suku bunga ditentukan sepenuhnya atas pertimbangan dari penyelenggara layanan pinjam meminjam uang berbasis teknologi informasi sebagaimana mengacu kepada ketentuan yang ada di dalam Pasal 17 Ayat (1) POJK Nomor 77 Tahun 2016.17 Dalam hemat Peneliti, meskipun Pasal 17 Ayat (1) POJK Nomor 77 Tahun 2016 terkesan memberikan kebebasan kepada penyelenggara dalam menetapkan besaran suku bunga dalam layanannya masing-masing, namun tetap memberikan batasan yang ideal.

Terkait batasan-batasan tersebut, yakni: (1) kewajaran, dan (2) perkembangan perekonomian nasional. Lebih lanjut terkait hal tersebut, mengacu kepada penjelasan yang ada di dalam Pasal 17 Ayat (1) POJK Nomor 77 Tahun 2016, dapat dipahami bahwa dalam hal penetapan besaran suku bunga yang wajar dapat diukur menggunakan dua parameter, yakni: (1) tingkat inflasi dan (2) kepentingan nasional. ${ }^{18}$ Lebih lanjut terkait hal tersebut, menurut Siwi Nur Indriyani, "inflasi adalah proses kenaikan harga-harga barang secara terus-menerus atau suatu keadaan perekonomian yang menunjukkan adanya kecenderungan kenaikan tingkat harga secara umum (price

\footnotetext{
14 Muhammad, A. (2005). Hukum dan Penelitian Hukum. Bandung: Citra Aditya Bakti. hlm. 52.

${ }^{15}$ Budhijanto, D. (2019). Hukum Ekonomi Digital. Bandung: Logoz Publishing. hlm, 25.

16 Ibid, hlm. 24.

17 Putra, K. S. W. \& Budiana, I. N. Op.Cit. hlm. 87.

18 Ibid.
} 
level)." 19 Lebih lanjut, menurut Siwi Nur Indriyani, ciri dari terjadinya inflasi dideskripsikan atas tiga hal, yakni: ${ }^{20}$

1. Terjadinya kenaikan harga, yakni harga atas suatu barang atau jasa tertentu saat ini lebih mahal dibandingkan harga atas barang atau jasa sebelumnya.

2. Bersifat umum atau sistemik, yakni kenaikan harga atas suatu barang atau jasa tertentu diikuti oleh kenaikan harga-harga atas barang atau jasa lainnya.

3. Berlangsung secara terus menerus, yakni kenaikan harga atas suatu barang atau jasa tertentu tersebut terjadinya tidak hanya sesaat melainkan terus menerus.

Berdasarkan hal tersebut dapat diketahui bahwa inflasi pada hakikatnya merupakan suatu kondisi dimana terjadinya kenaikan harga atas suatu barang atau jasa tertentu yang juga diikuti oleh kenaikan harga atas suatu barang atau jasa tertentu yang terus menerus selama periode tertentu. Kemudian terkait konteks dari parameter penetapan besaran suku bunga dalam layanan pinjam meminjam uang berbasis teknologi yang ideal, selain mempertimbangkan tingkat inflasi juga mempertimbangkan hal-hal yang berkaitan dengan kepentingan nasional.

Terkait Kepentingan nasional secara etimologis berasal dari konsep dalam bahasa Prancis, raison d'État, yakni tujuan dan ambisi negara, baik ekonomi, militer, atau budaya. ${ }^{21}$ Lebih lanjut terkait hal kepentingan negara di bidang ekonomi, sebagaimana amanat konstitusi yang ada di dalam ketentuan Pasal 33 Ayat (4) Undang-Undang Dasar Negara Republik Indonesia pada hakikatnya berorientasi kepada terwujudnya keseimbangan, kemajuan dan kesatuan ekonomi nasional melalui demokrasi ekonomi yang dilaksanakan dengan prinsip-prinsip: (1) kebersamaan, (2) efisiensi berkeadilan, (3) berkelanjutan, (4) berwawasan lingkungan, dan (5) kemandirian.22 Adapun salah satu kepentingan negara di bidang ekonomi yakni menjaga kestabilan perekonomian nasional dan nilai rupiah dalam bentuk kebijakan moneter yang dimandatkan kepada Bank Indonesia (selanjutnya disebut BI) sebagaimana amanat dari Pasal 7 UndangUndang Nomor 6 Tahun 2009 tentang Penetapan Peraturan Pemerintah Pengganti Undang-Undang Nomor 2 Tahun 2008 tentang Perubahan Kedua Atas UndangUndang Nomor 23 Tahun 1999 tentang Bank Indonesia Menjadi Undang-Undang (Selanjutnya disebut UU Nomor 6 Tahun 2009). Adapun salah satu bentuk kebijakan moneter yang dilakukan antara lain melalui pengendalian jumlah uang beredar dan suku bunga. ${ }^{23}$

Adapun terkait hal tersebut, secara eksplisit Pasal 17 POJK Nomor 77 Tahun 2016 sebagai lex specialis dalam kegiatan layanan pinjam meminjam uang berbasis teknologi informasi memberikan kewenangan kepada penyelenggara untuk menentukan suku

${ }^{19}$ Indriyani, S. N. (2016). Analisis Pengaruh Inflasi dan Suku Bunga Terhadap Pertumbuhan Ekonomi di Indonesia Tahun 2005-2015. Jurnal Manajemen Bisnis Krisnadwipayana, 4(2), 1-11. h. 8.

${ }^{20}$ Ibid.

${ }^{21}$ Bainus, A., \& Rachman, J. B. (2018). Editorial: Kepentingan Nasional dalam Hubungan Internasional. Intermestic: Journal of International Studies, 2(2), 109-115. h. 109.

${ }^{22}$ Arifin, M. Y., Putra, A. H. P. K., \& Buana, A. P. (2019). Perekonomian Nasional Dalam Prespektif Undang-Undang Dasar 1945 Negara Republik Indonesia. Celebes Equilibrum Journal, 1(1), 18-31. h. 30.

${ }^{23}$ Gultom, M. S. (2014). Analisis Kebijakan Moneter Islam M. Umer Champra. Pascasarjana UIN Sumatera Utara: Thesis. h. 40. 
bunga di dalam layanannya masing-masing, sedangkan di sisi lainnya juga terdapat Pedoman Perilaku (Code of Conduct) yang dikeluarkan oleh AFPI yang membatasi perilaku penyelenggara layanan pinjam meminjam uang berbasis teknologi informasi agar menetapkan bunga dalam layanannya tidak melebihi dari $0,8 \%$ per hari. ${ }^{24} \mathrm{Hal}$ tersebut dalam hemat Peneliti, secara tidak langsung menjadi asas penyelenggaraan dalam penentuan suku bunga dalam pasar layanan pinjam meminjam uang berbasis teknologi informasi. Padahal, seluruh suku bunga yang beredar di dalam pasar layanan pinjam meminjam uang berbasis teknologi informasi pada hakikatnya berpengaruh langsung terhadap tingkat inflasi, yang mana apabila dikaitkan dengan kebijakan moneter yang diamanatkan oleh UU Nomor 6 Tahun 2009 salah satunya ialah penargetan inflasi. ${ }^{25}$ Akan tetapi, BI selaku lembaga yang berwenang dan bertanggung jawab dalam penargetan inflasi dalam hal pengendalian suku bunga yang beredar di dalam pasar layanan pinjam meminjam uang berbasis teknologi informasi tidak diberikan kewenangan sama sekali berdasarkan ketentuan yang ada di dalam Pasal 17 POJK Nomor 77 Tahun 2016 dan asas penyelenggaraannya.

Hal tersebut secara tidak langsung mendestruksi tatanan makroekonomi yang ada, sebab tentangan makroekonomi yang ideal menurut konstruksi peraturan perundangundangan yang ada pada hakikatnya berparadigma kepada kewenangan BI dalam melaksanakan kebijakan moneter melalui penargetan inflasi. Terkait hal tersebut, pada hakikatnya salah satu faktor penting dalam efektivitas penargetan inflasi adalah kecenderungan bunga yang beredar di dalam kegiatan intermediasi sebagaimana hal tersebut ditunjukkan di dalam Penelitian Salvere P. Roeroe, et all,26 maka sudah semestinya hal tersebut juga diterapkan di dalam kegiatan layanan pinjam meminjam uang berbasis teknologi informasi. Sehingga kehadiran BI di dalam kegiatan layanan pinjam meminjam uang berbasis teknologi informasi adalah hal yang mutlak agar penargetan inflasi dapat berjalan secara efektif.

Pengintegrasian kebijakan moneter di dalam kegiatan layanan pinjam meminjam uang berbasis teknologi informasi pada hakikatnya adalah suatu hal yang krusial untuk mengharmonisasi atau menyatukan seluruh variabel sistem yang ada di dalam konstruksi hukum layanan pinjam meminjam uang berbasis teknologi informasi. Kondisi tersebutlah yang disebut sebagai kondisi yang ideal sebagaimana paradigma dari teori konvergensi hukum. Terkait hal tersebut, teori konvergensi hukum yang digagas oleh Danrivanto Budhijanto pada hakikatnya berparadigma kepada penyatuan (convergence) seluruh variabel-variabel seperti variabel teknologi, variabel ekonomi, serta variabel hukum terhadap hubungan manusia dan masyarakat di era informasi digital, baik dalam tataran nasional, daerah maupun internasional. ${ }^{27}$ Adapun kebaruan konstruksi hukum yang digagas oleh Peneliti, yakni penentuan suku bunga dalam layanan pinjam meminjam uang berbasis teknologi informasi yang ditetapkan oleh BI pada hakikatnya merupakan hasil perenungan dari penyatuan seluruh

\footnotetext{
${ }^{24}$ Tjandra, A. (2020). Op.Cit. h. 101.

${ }^{25}$ Yeni, P., Syamsul, A., \& Satrianto, A. (2018). Pengaruh Suku Bunga, Loan to Deposit Ratio (LDR) dan Pertumbuhan Kredit terhadap Inflasi di Indonesia. Jurnal EcoGen, 1(3), 557-566. h. 557.

${ }^{26}$ Roeroe, S. P., Kumaat, R. J., \& Mandeij, D. (2020). Efektivitas Penerapan Inflation Targeting Framework Terhadap Tingkat Inflasi Di Indonesia. Jurnal Berkala Ilmiah Efisiensi, 20(3), 99-109. h. 108.

${ }^{27}$ Danrivanto Budhijanto, Hukum Ekonomi Digital di Indonesia, Loc.Cit.
} 
variabel-variabel seperti variabel teknologi, variabel makroekonomi dan variabel hukum sebagaimana paradigma teori konvergensi hukum.

Terkait hal tersebut, penentuan suku bunga dalam layanan pinjam meminjam uang berbasis teknologi informasi dalam hal ini bertransformasi menjadi ranah kebijakan moneter dengan BI berperan sebagai pengambil keputusan (decision maker) dan dapat mengintegrasikan efektivitas penargetan inflasi dalam tataran nasional maupun daerah. Apabila penargetan inflasi dapat berjalan secara efektif, maka secara langsung juga akan mempengaruhi kepada keberhasilan kebijakan moneter dalam mencapai dan memelihara kestabilan nilai rupiah. Apabila kestabilan nilai rupiah dapat terpelihara dan tercapai, maka juga akan berpengaruh langsung kepada ketahanan perekonomian nasional yang dampaknya sangat efektif terhadap kesejahteraan masyarakat. ${ }^{28}$ Keadaan inilah yang dalam hemat Peneliti sebagai keadaan ideal untuk tercapainya salah satu parameter demokrasi ekonomi sebagaimana merupakan amanat kesejahteraan sosial yang berdasarkan Pancasila dan Undang-Undang Dasar Negara Republik Indonesia Tahun $1945 .{ }^{29}$

Berikut merupakan sebuah visualisasi konstruksi hukum ideal penentuan suku bunga dalam layanan pinjam meminjam uang berbasis teknologi informasi yang digagas oleh Peneliti berdasarkan prinsip konvergensi hukum:

${ }^{28}$ Rosa, Y. D., Agus, I., \& Abdilla, M. (2019). Pengaruh Inflasi, Kebijakan Moneter dan Pengangguran Terhadap Perekonomian Indonesia. Jurnal Ekonomi dan Bisnis Dharma, 21(2), 283-293. h. 286.

${ }^{29}$ Ruslina, E. (2016). Makna Pasal 33 Undang-Undang Dasar 1945 dalam Pembangunan Hukum Ekonomi Indonesia. Jurnal Konstitusi, 9(1), 49-82. h. 61. 


\section{Skema 1}

Konstruksi Hukum Penentuan Suku Bunga dalam Layanan Pinjam Meminjam Uang Berbasis Teknologi Informasi

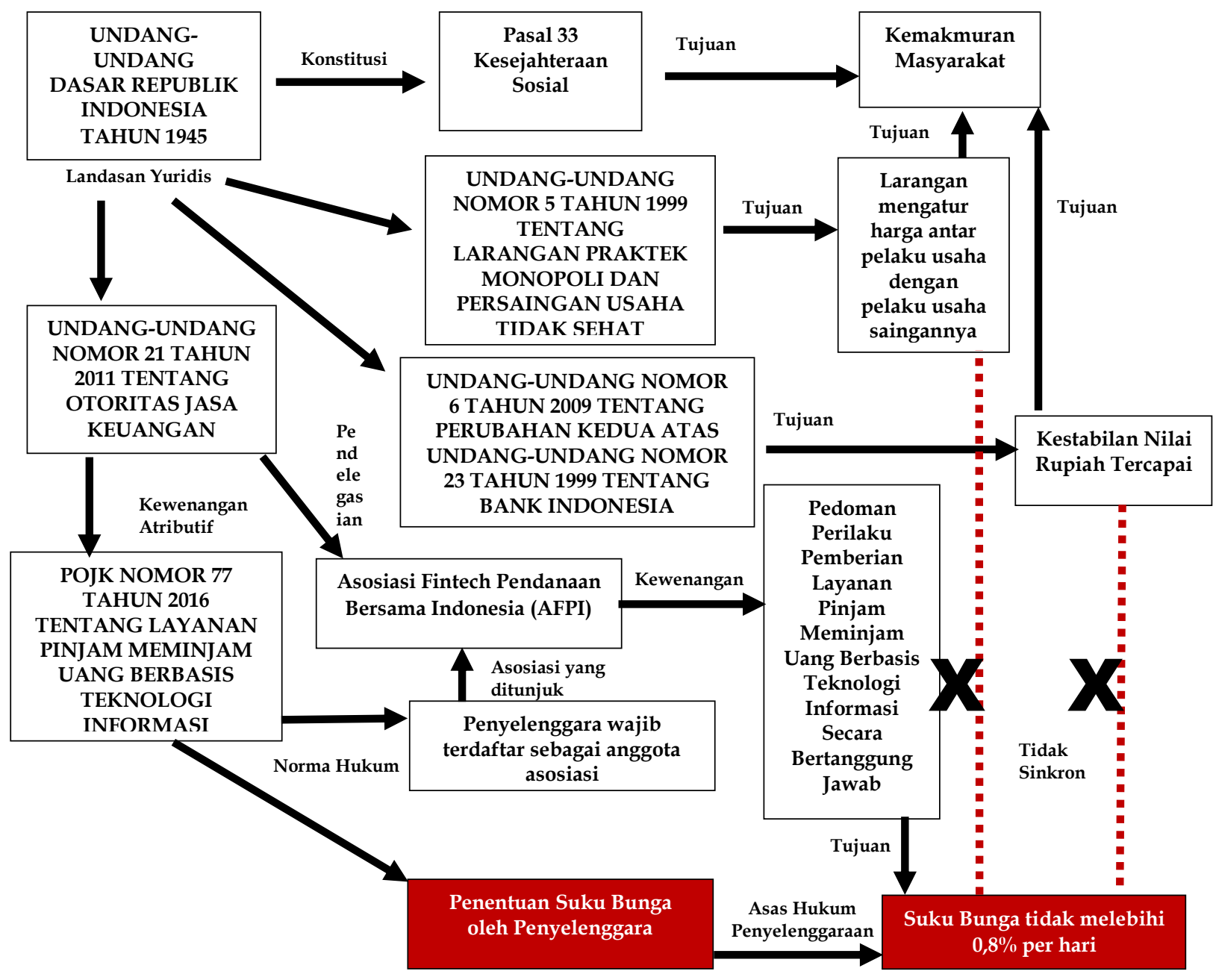


Skema 2

Konstruksi Hukum Penentuan Suku Bunga dalam Layanan Pinjam Meminjam Uang Berbasis Teknologi Informasi Gagasan Peneliti

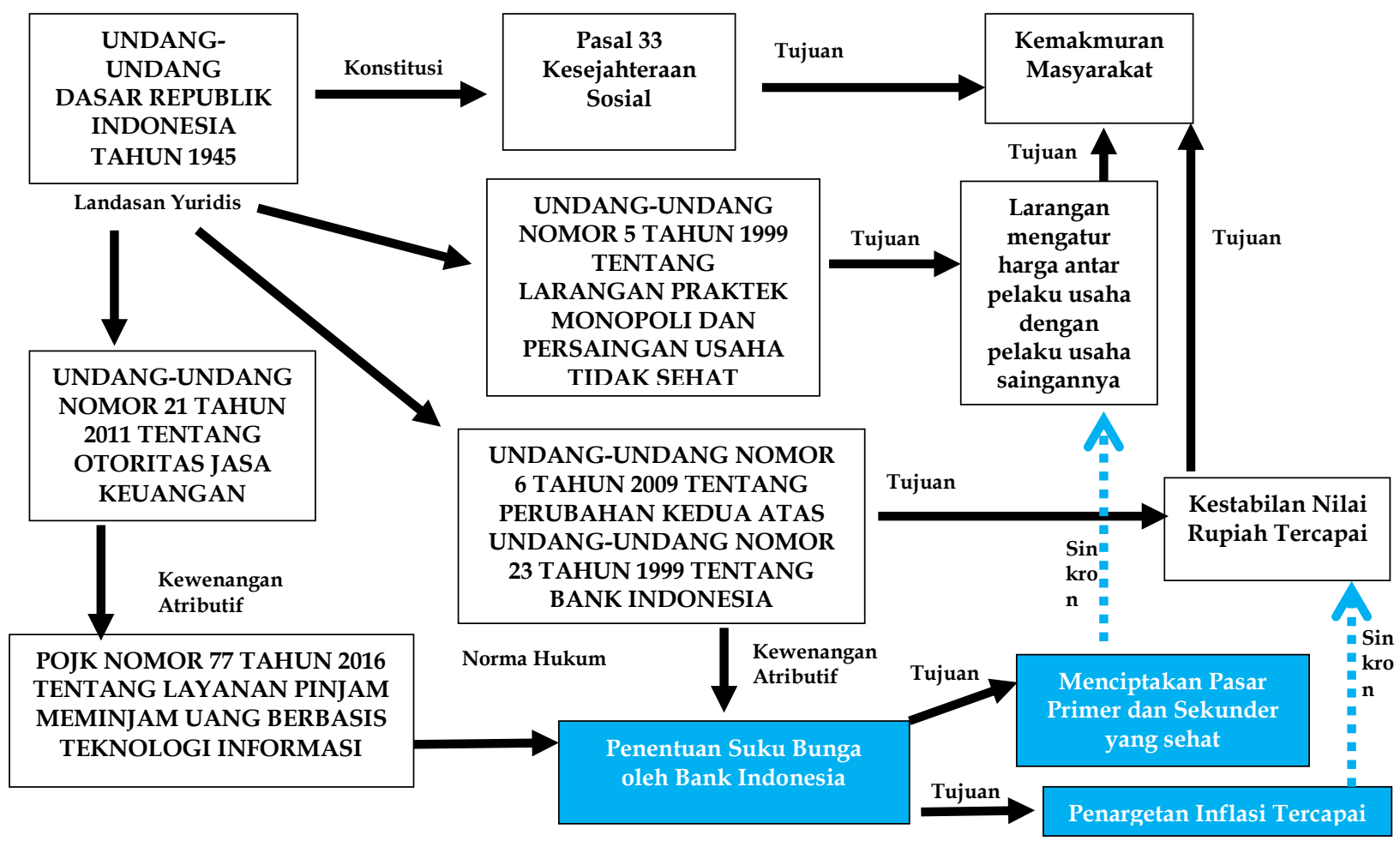


Berdasarkan kedua Skema tersebut dapat diketahui bahwa konstruksi penentuan suku bunga dalam layanan pinjam meminjam uang berbasis teknologi informasi yang ada saat ini secara normatif tidak sinkron antara tujuan peraturan perundang-undangan di hierarki yang lebih tinggi dengan tujuan dari Pedoman Perilaku AFPI. Meskipun dapat dipahami bahwa substansi Pedoman Perilaku yang diatur oleh AFPI bersifat terbatas hanya mengatur anggotanya saja yang mana adalah seluruh penyelenggara layanan pinjam meminjam uang berbasis teknologi informasi terdaftar dan POJK Nomor 77 Tahun 2016 tetap berlaku secara publik, akan hal yang diatur di dalam Pedoman Perilaku AFPI secara langsung mempengaruhi implementasi dari Pasal 17 POJK Nomor 77 Tahun 2016 itu sendiri yang mana secara tidak langsung menimbulkan ketidakharmonisan dalam tujuan hukum yang dibangun pada tataran hierarki Undang-Undang dan Peraturan Pemerintah Pengganti Undang-Undang (Perppu). Adapun konstruksi hukum yang digagas oleh Peneliti mampu menjawab permasalahan tersebut. Hal tersebut dapat terlihat dari tujuan hukum yang akan dicapai selaras atau sinkron dengan tujuan hukum yang dibangun pada tataran hierarki di atasnya.

Terkait hal tersebut berikut dasar alasan dalam hemat Peneliti, Pertama, penentuan suku bunga oleh Bank Indonesia sejalan dengan tujuan UU Nomor 6 Tahun 2009, bahwa dengan diberikan kewenangan atributif kepada BI untuk terlibat langsung pada penentuan suku bunga dalam layanan pinjam meminjam uang berbasis teknologi informasi akan memberikan ruang kepada BI untuk mengintegrasikannya ke dalam kebijakan moneter yang bertujuan kepada penargetan inflasi. Apabila BI dapat secara langsung mempengaruhi penentuan suku bunga pada penentuan suku bunga dalam layanan pinjam meminjam uang berbasis teknologi informasi, maka BI juga akan mampu mempengaruhi aktivitas kegiatan perekonomian berdasarkan tujuan penargetan inflasi yang ada melalui mekanisme transmisi kebijakan moneter dengan melakukan/tidak melakukan perubahan terhadap suku bunga acuan. Sehingga dengan demikian penargetan inflasi akan lebih efektif dibandingkan dengan konstruksi hukum penentuan suku bunga dalam layanan pinjam meminjam uang berbasis teknologi informasi yang ada saat ini.

Kedua, penentuan suku bunga oleh Bank Indonesia sejalan dengan tujuan UndangUndang Nomor 5 Tahun 1999, bahwa yang menjadi permasalahan utama di dalam konstruksi hukum penentuan suku bunga dalam layanan pinjam meminjam uang berbasis teknologi informasi yang ada saat ini adalah penentuan suku bunga secara langsung di limitasi oleh AFPI yang mana merupakan asosiasi penyelenggara layanan pinjam meminjam uang berbasis teknologi informasi yang dikelola oleh para penyelenggara layanan pinjam meminjam uang berbasis teknologi informasi dan memiliki tujuan untuk menaungi para penyelenggara layanan pinjam meminjam uang berbasis teknologi informasi yang menjadi anggotanya. Hal tersebut selain menimbulkan konflik kepentingan juga menciptakan posisi dominan dengan menentukan ambang batas suku bunga yang menjadi acuan penyelenggara layanan pinjam meminjam uang berbasis teknologi informasi. ${ }^{30}$ Lebih lanjut, dengan penentuan suku bunga acuan ditetapkan oleh BI maka selain bebas dari konflik kepentingan yang ada juga secara langsung menciptakan pasar primer yang sehat dan secara tidak langsung juga berpotensi menciptakan pasar sekunder yang sehat.

${ }^{30}$ Handayani, O. \& Sulistiyono, A. Op.Cit. h. 250. 
Terkait pasar primer, pada hakikatnya kegiatan layanan pinjam meminjam uang dalam hemat Peneliti bersifat lebih seperti obligasi dengan penawaran (supply) bersumber dari bunga yang ditawarkan kepada calon pemberi pinjaman dan permintaan (demand) bersumber dari pengajuan pinjaman calon penerima pinjaman dalam layanan pinjam meminjam uang berbasis teknologi informasi. Terkait hal tersebut, posisi penawaran (supply) dan permintaan (demand) tentu akan sangat dipengaruhi oleh trend suku bunga yang ada saat ini, idealnya pasar yang bebas secara sendirinya akan mampu mengkoreksi sendiri ekuivalen penawaran (supply) dan permintaan (demand) yang ada. Akan tetapi, apabila pasar dibiarkan bebas tanpa terintegrasi dengan kebijakan moneter maka dampaknya pasar akan sangat rentan terhadap inflasi, mengingat inflasi pada hakikatnya bersifat tidak terhingga. Sehingga untuk mengantisipasi hal demikian, maka perlu dilakukan sebuah intervensi dari BI untuk mengintegrasikan pasar dalam layanan pinjam meminjam uang berbasis teknologi informasi dengan penargetan inflasi melalui penentuan suku bunga dalam dalam layanan pinjam meminjam uang berbasis teknologi informasi.

Lalu kemudian terkait pasar sekunder, penentuan suku bunga oleh BI yang dinamis atau tidak statis sebagaimana yang ditetapkan oleh AFPI di dalam Pedoman Perilaku akan menciptakan kemungkinan cessie atau pengalihan piutang melalui jual beli berdasarkan margin selisih suku bunga yang ditetapkan pada saat perjanjian pinjam meminjam uang berbasis teknologi informasi dilakukan dan pada saat sedang berjalan. Hal tersebut dapat terjadi karena margin selisih penetapan suku bunga pada saat perjanjian pinjam meminjam uang berbasis teknologi informasi dilakukan dan pada saat ditawarkan pengalihan piutang menjadi pertimbangan ekonomis baik bagi pihak pemilik piutang asal maupun calon pembeli. Terlebih faktanya penetapan suku bunga yang dijalankan oleh BI selama ini menjadi sumber informasi yang mempengaruhi pelaku pasar dalam pasar investasi, ${ }^{31}$ termasuk pasar sekunder perjanjian pinjam meminjam uang berbasis teknologi informasi apabila terealisasi.

Hal tersebut secara tidak langsung memberikan pilihan hukum dan ekonomi bagi pemberi pinjaman selama perjanjian pinjam meminjam uang berbasis teknologi informasi sedang berjalan dengan mekanisme pasar. Sehingga dengan demikian penentuan suku bunga yang dinamis oleh BI selain bebas dari konflik kepentingan yang ada juga berpotensi menciptakan pasar yang ideal dalam layanan pinjam meminjam uang berbasis teknologi informasi.

Berdasarkan beberapa alasan di atas dapat disimpulkan bahwa konstruksi hukum yang digagas oleh Peneliti pada hakikatnya telah konvergensif, mengingat konstruksi hukum yang digagas disusun berdasarkan pertimbangan seluruh variabel yang ada, yakni teknologi finansial, makroekonomi dan harmonisasi hukum. Lebih lanjut, konstruksi hukum yang digagas oleh Peneliti juga secara langsung mencerminkan prinsip keadilan dalam layanan pinjam meminjam uang berbasis teknologi informasi. Hal tersebut didasarkan kepada premis bahwa yang paling rentan dirugikan (high risk) oleh konstruksi hukum penentuan suku bunga dalam layanan pinjam meminjam uang berbasis teknologi informasi saat ini pada hakikatnya adalah pihak pemberi pinjaman. Menanggapi hal tersebut, sebagaimana tujuan keadilan yang ideal menurut John

\footnotetext{
${ }^{31}$ Mahendra, I. K. R. \& Rasmini, N. K. 2019. Reaksi Pasar Terhadap Kenaikan Bank Indonesia 7Day Reverse Repo Rate Tanggal 15 Agustus 2018. E-Jurnal Akuntansi, 27(3), 2066-2099. DOI: https://doi.org/10.24843/EJA.2019.v27.i03.p16.
} 
Rawls adalah keadilan yang layak (justice is fairness), sehingga berdasarkan pijakan dasar tersebut John Rawls menjabarkan sebagai berikut:

"The social system is to be designed so that the resulting distribution is just, however things turn out. To achieve this end it is necesarry to set the social and economic process within the surroundings of suitable political and legal institusions. Without the proper arrangement of this background institutions, the outcome of the distributive process will not be just." 32

(Terjemahan bebas dari Peneliti)

Sistem sosial di fabrikasi sedemikian rupa agar hasil pendistribusian berjalan dengan adil, terlepas apapun hasilnya. Untuk dapat mencapai keadaan ini perlu diatur sedemikian rupa tatanan sosial dan ekonomi melalui institusi politik dan hukum yang sesuai. Lebih lanjut, apabila hal tersebut dilakukan dengan tanpa tata pengaturan yang baik maka hasil pendistribusian akan tetap tidak adil.

Menurut John Rawls, bahwa keadilan haruslah berparadigma kepada sistem sosial yang di rekayasa sedemikian rupa melalui institusi politik dan hukum yang Berdasarkan gagasan tersebut, Peneliti dalam hal ini mengkontekstualkan bahwa konstruksi hukum penentuan suku bunga dalam layanan pinjam meminjam uang berbasis teknologi informasi saat ini sangat tidak adil bagi pemberi pinjaman. Hal ini dapat terlihat dari konstruksi hukum dan asas hukum penyelenggaraan penentuan suku bunga dalam layanan pinjam meminjam uang berbasis teknologi informasi saat ini menciptakan pasar yang tidak sehat melalui penetapan bunga yang tidak dinamis melalui posisi dominan AFPI dalam kegiatan layanan pinjam meminjam uang berbasis teknologi informasi saat ini, sehingga dalam hal ini kemungkinan terciptanya pasar sekunder yang ideal sangat tidak memungkinkan.

Terkait hal tersebut, dengan terciptanya pasar sekunder dalam layanan pinjam meminjam uang berbasis teknologi informasi akan memberikan variasi pilihan hukum dan ekonomi bagi pemberi pinjaman. sesuai agar pendistribusian di dalam pasar dapat berjalan dengan adil tanpa terlepas apapun hasilnya. Adapun terkait hal tersebut, dalam hemat Peneliti konsep justice is fairness yang digagas oleh John Rawls dapat dikontekstualkan ke dalam apakah tatanan atau sistem yang dibentuk oleh konstruksi hukum dan politik yang ada saat ini memberikan pilihan yang beragam bagi para pihak di dalamnya. Lebih lanjut, ragam atau variasi pilihan hukum dan ekonomi bagi para pihak penting dalam upaya mengkoreksi ketidakadilan (unfairness) yang terjadi karena variabel-variabel yang ada di dalam sistem tersebut, dalam hal ini layanan pinjam meminjam uang berbasis teknologi informasi.

Contoh, ketika pemberi pinjaman merasa dirugikan terhadap perjanjian pinjam meminjam uang berbasis teknologi informasi yang wanprestasi pada saat itu, maka pemberi pinjaman dapat melakukan upaya menjual hak piutangnya (cessie) kepada pihak lain dengan dasar perbandingan acuan suku bunga yang ditentukan oleh BI pada saat perjanjian dilakukan dengan pada saat penawaran di pasar sekunder dilakukan, mengingat karakteristik dari suku bunga yang ditentukan oleh BI pasti bersifat dinamis.

32 Rawls, J. 1971. A Theory of Justice. Cambridge: The Belknap Press of Harvard University Press. h. 275. 
Berbeda halnya dengan konstruksi hukum penentuan suku bunga dalam layanan pinjam meminjam uang berbasis teknologi informasi saat ini yang bersifat tidak dinamis, kemungkinan penawaran hak piutang (cessie) di pasar sekunder akan sulit menemukan peminat (demand). Hal tersebut dalam hemat Peneliti disebabkan karena lesunya motif pasar. Terlepas penawaran hak piutang (cessie) di pasar sekunder ditawarkan dengan harga merugi sekali pun, dengan karakteristik bunga di pasar layanan pinjam meminjam uang berbasis teknologi informasi yang tidak dinamis akan memberikan kesan tidak bernilai karena lebih minim risiko apabila berspekulasi di pasar primer karena hampir tidak ada selisih antara bunga pada saat perjanjian pinjam meminjam uang berbasis teknologi informasi dilakukan dengan pada saat hak piutang (cessie) ditawarkan di pasar sekunder. Sehingga berdasarkan alasan-alasan tersebut konstruksi hukum penentuan suku bunga dalam layanan pinjam meminjam uang berbasis teknologi digagas oleh Peneliti, yakni penentuan suku bunga dalam layanan pinjam meminjam uang berbasis teknologi informasi yang mengacu kepada suku bunga yang ditetapkan oleh BI sebagai cerminan dari prinsip-prinsip konvergensi hukum dan keadilan.

\section{Kesimpulan}

Konstruksi hukum penentuan suku bunga pada layanan pinjam meminjam uang berbasis teknologi informasi eksisting saat ini pada hakikatnya belum terintegrasi dengan variabel-variabel terkait, baik dalam perspektif ekonomi, teknologi, hukum dan keadilan yang berkaitan dengan kebijakan moneter dan persaingan usaha yang sehat. Dengan demikian pada hakikatnya perlu dilakukan pengkonstruksian hukum baru yang ideal, yakni berprinsip kepada konvergensi hukum dan keadilan. Terkait hal tersebut, konstruksi hukum yang ideal menurut Peneliti adalah penentuan suku bunga yang mengacu kepada suku bunga yang ditetapkan oleh Bank Indonesia.

Harapan Peneliti, Bank Indonesia, Otoritas Jasa Keuangan dan Asosiasi Fintech Pendanaan Bersama Indonesia, dapat menyesuaikan dan menerapkan konstruksi hukum penentuan suku bunga dalam layanan pinjam meminjam uang berbasis teknologi informasi saat ini menjadi penentuan suku bunga yang mengacu kepada suku bunga yang ditetapkan oleh Bank Indonesia.

\section{Daftar Pustaka}

\section{Buku}

Budhijanto, D. (2019). Hukum Ekonomi Digital. Bandung: Logoz Publishing. Muhammad, A. (2005). Hukum dan Penelitian Hukum. Bandung: Citra Aditya Bakti. Rawls, J. (1971). A Theory of Justice. Cambridge: The Belknap Press of Harvard University Press.

\section{Jurnal}

Arifin, M. Y., Putra, A. H. P. K., \& Buana, A. P. (2019). Perekonomian Nasional Dalam Prespektif Undang-Undang Dasar 1945 Negara Republik Indonesia. Celebes Equilibrum Journal, 1(1), 18-31.

Bainus, A \& Rachman, J. B. (2018). Editorial: Kepentingan Nasional dalam Hubungan Internasional. Intermestic: Journal of International Studies, 2(2), 109-115. 
Budiyanti, E. (2019). Upaya Mengatasi Layanan Pinjaman Online Ilegal. Info Singkat, 11(4), 19-24.

Handayani, O. \& Sulistiyono, A. (2020). Pembadanan Hukum Fintech Sebagai Instrumen Pengaturan Persaingan Usaha yang Sehat. Masalah-Masalah Hukum, 49(3), 244-255.

Indriyani, S. N. (2016). Analisis Pengaruh Inflasi dan Suku Bunga Terhadap Pertumbuhan Ekonomi di Indonesia Tahun 2005-2015. Jurnal Manajemen Bisnis Krisnadwipayana, 4(2), 1-11.

Mahendra, I. K. R. \& Rasmini, N. K. 2019. Reaksi Pasar Terhadap Kenaikan Bank Indonesia 7-Day Reverse Repo Rate Tanggal 15 Agustus 2018. E-Jurnal Akuntansi, 27(3), 2066-2099. DOI: https://doi.org/10.24843/EJA.2019.v27.i03.p16.

Mustaqim, A. H. (2010). Otoritas Jasa Keuangan Sebagai Solusi Sistem Ekonomi Nasional. Jurnal Hukum Perspektif, 8(1), 70-80.

Putra, K. S. W. \& Budiana, I. N. 2019. Perjanjian Kredit Melalui Financial Technology Dalam Lalu Lintas Hukum Bisnis. Jurnal Analisis Hukum, 2(1), 73-92.

Roeroe, S. P., Kumaat, R. J., \& Mandeij, D. (2020). Efektivitas Penerapan Inflation Targeting Framework Terhadap Tingkat Inflasi Di Indonesia. Jurnal Berkala Ilmiah Efisiensi, 20(3), 99-109.

Rosa, Y. D., Agus, I., \& Abdilla, M. (2019). Pengaruh Inflasi, Kebijakan Moneter dan Pengangguran Terhadap Perekonomian Indonesia. Jurnal Ekonomi dan Bisnis Dharma, 21(2), 283-293.

Ruslina, E. (2016). Makna Pasal 33 Undang-Undang Dasar 1945 dalam Pembangunan Hukum Ekonomi Indonesia. Jurnal Konstitusi, 9(1), 49-82.

Saputra, A. S. (2019). Peer To Peer Lending di Indonesia dan Beberapa Permasalahannya. Veritas et Justitia, 5(1), 238-261.

Tjandra, A. (2020). Kekosongan Norma Penentuan Bunga Pinjaman Financial Technology Peer To Peer Lending. Jurnal Hukum Bisnis Bonum Commune, 3(1), 90-103.

Yeni, P., Syamsul, A., \& Satrianto, A. (2018). Pengaruh Suku Bunga, Loan to Deposit Ratio (LDR) dan Pertumbuhan Kredit terhadap Inflasi di Indonesia. Jurnal EcoGen, 1(3), 557-566.

Tesis/Disertasi

Gultom, M. S., (2014). Analisis Kebijakan Moneter Islam M. Umer Champra. Pascasarjana UIN Sumatera Utara.

\section{Online/World Wide Web:}

LAPOR. Otoritas Jasa Keuangan. (2019). https://www.lapor.go.id/instansi/otoritasjasa-keuangan/process, diakses pada tanggal 4 Juli 2019.

Otoritas Jasa Keuangan. Perkembangan Fintech Lending (Pendanaan Gotong Royong on-Line). (2019). $\quad$ https://www.ojk.go.id/id/kanal/iknb/data-danstatistik/fintech/Pages/Statistik-Fintech-Lending-Periode-Juli-2019.aspx, diakses pada tanggal 18 September 2019.

\section{Peraturan Perundang-Undangan}

Undang-Undang Dasar Negara Republik Indonesia Tahun 1945.

Undang-Undang Nomor 5 Tahun 1999 tentang Larangan Praktek Monopoli dan Persaingan Usaha Tidak Sehat 
Undang-Undang Nomor 6 Tahun 2009 tentang Penetapan Peraturan Pemerintah Pengganti Undang-Undang Nomor 2 Tahun 2008 tentang Perubahan Kedua Atas Undang-Undang Nomor 23 Tahun 1999 tentang Bank Indonesia Menjadi Undang-Undang.

Undang-Undang Nomor 21 Tahun 2011 tentang Otoritas Jasa Keuangan.

Peraturan Otoritas Jasa Keuangan Nomor 77/POJK.01/2016 tentang Layanan Pinjam Meminjam Uang Berbasis Teknologi Informasi. 